\title{
The biopsy pathology of non-coeliac enteropathy
}

\author{
Joel K Greenson \\ University of Michigan Medical Center, Ann Arbor, MI, USA
}

\author{
Greenson J K \\ (2015) Histopathology 66, 29-36. DOI: 10.1111/his.12522
}

\section{The biopsy pathology of non-coeliac enteropathy}

Tropical sprue (TS) is a malabsorption syndrome of presumed infectious aetiology that affects residents of (or visitors to) the tropics. The histological changes of TS are similar to those of coeliac disease, with increased intraepithelial lymphocytes being central to both. Unlike in coeliac disease, however, a completely flat small bowel biopsy is uncommon in TS. TS typically involves the terminal ileum, whereas coeliac disease does not. Small intestinal bacterial overgrowth (SIBO) has been defined as an increase in number and/or a change in the type of bacteria in the upper gut. Conditions that predispose to SIBO are largely those that decrease or interfere with small bowel motility. The mucosal histology is variable, and may include modest villous blunting accompanied by increased lamina propria and epithelial inflammation. Autoimmune enteropathy (AE) is a family of rare diseases that share common themes such as immunodeficiency states and autoantibodies. AE cases typically have marked villous atrophy similar to that in fully developed coeliac disease, but they lack the intense surface epithelial lymphocytosis. Apoptosis and lymphocyte infiltration at the base of the crypts, crypt abscesses and cryptitis are also seen. Patients with anti-goblet cell antibodies can have a lack of goblet cells, endocrine cells, and Paneth cells.

Keywords: autoimmune enteropathy, bacterial overgrowth, tropical sprue

\section{Introduction}

Most small bowel biopsies are taken to rule out coeliac disease and, given that endoscopic biopsies are screening tests, the vast majority of these biopsies are normal (an audit of 6 months of small bowel biopsies at my own institution found that $93 \%$ of biopsies were histologically normal). This article will focus on non-coeliac causes of enteropathy, which is a small subset of small bowel biopsy pathology. This subset is even smaller because drug-induced enteropathy and enteropathy-associated lymphomas will be covered in other sections of this journal. Generically speaking, enteropathy refers to any pathological process of the intestine. This review article, however, will focus on non-coeliac disorders that enter into the differential

Address for correspondence: J K Greenson, University of Michigan Medical Center, Room 5218, Box 5602, Medical Science Building 1, 1301 Catherine Street, Ann Arbor, MI 48109-5602, USA. e-mail: facjkgmd@umich.edu diagnosis of coeliac disease in small bowel biopsies, namely bacterial overgrowth, tropical sprue and autoimmune enteropathy.

\section{Tropical sprue}

Tropical sprue (TS) is an intestinal malabsorption syndrome of unknown but presumed infectious aetiology that affects residents of (or visitors to) the tropics. ${ }^{1}$ The disease has been found to be both endemic to and epidemic in a wide variety of places located between $30^{\circ}$ north and south of the equator, including India, Southeast Asia, West Africa, northern South America, and several locations in the Caribbean. $^{2,3}$ There are references to a disease similar to TS dating back to $1600 \mathrm{Bc}{ }^{3,4}$ but modern medicine only recognized it during the 1960s, when epidemics killing as many as 35000 people occurred in southern India. ${ }^{1,3}$

Although the exact infectious pathogen or pathogens that cause TS remain a mystery, there is 
convincing evidence that TS is indeed an infectious process (so much so that another name for the condition is postinfective tropical malabsorption). It occurs in geographical regions where enteric infections are common, in some areas it is epidemic, and recovery after treatment with broad-spectrum antibiotics, as well as $B_{12}$ and folate replacement, is usually rapid and dramatic. ${ }^{1,3,5}$ It has been shown that overgrowth of aerobic bacteria occurs in TS patients, and that these bacteria may be toxin-producing. ${ }^{6,7}$ Others have postulated viral or even parasitic infection as a cause, but to date there are no convincing data on the actual pathogen responsible. ${ }^{8,9}$ Although TS is not a common diagnosis in the USA and Europe, it is thought to account for up to $40 \%$ of malabsorption cases in Southern Asia. ${ }^{5}$ The Aw-19 HLA haplotype series appears to increase the risk of TS, suggesting that innate immunity may also play a role in disease pathogenesis. $^{10}$

The symptoms of TS can be broken down into acute and chronic phases, and seem to differ between visitors to the tropics and those indigenous to the area. In visitors, the onset is often insidious, but acute diarrhoea with abdominal pain, nausea, and flatulence, as well as systemic symptoms such as fever, myalgia, and weakness, may also occur. ${ }^{4}$ Fat malabsorption is uniformly present. The chronic changes of TS typically occur in indigenous populations, and include not only acute diarrhoea and malabsorption, but also secondary folate and $\mathrm{B}_{12}$ deficiencies, which may take 2-4 years to develop. ${ }^{4}$ These nutritional deficiencies may lead to glossitis, stomatitis, and megaloblastic anaemia.

The histological changes of TS are very similar to those of coeliac disease, as an increase in the number of intraepithelial lymphocytes is central to the pathology of both conditions (Figure 1A,B). Unlike in coeliac disease, however, a completely flat small bowel biopsy is uncommon in $\mathrm{TS}^{2,11,12}$ (Figure 1A). A recent review by Brown et al. found that nine of 12 TS patients had partial villous blunting, whereas three had normal villous architecture. ${ }^{2}$ All 12 patients had increased numbers of intraepithelial lymphocytes, but none had a flat (Marsh 3C) small bowel biopsy. ${ }^{2}$ This same study found that there were significantly more eosinophils in the lamina propria of duodenal biopsies of TS patients than in those of coeliac disease patients. The distribution of disease is also different between TS and coeliac disease. ${ }^{2,13}$ Coeliac disease tends to involve the proximal small bowel (sparing the terminal ileum), and hence leads to iron deficiency anaemia, whereas TS involves the entire small bowel, including the terminal ileum, leading to
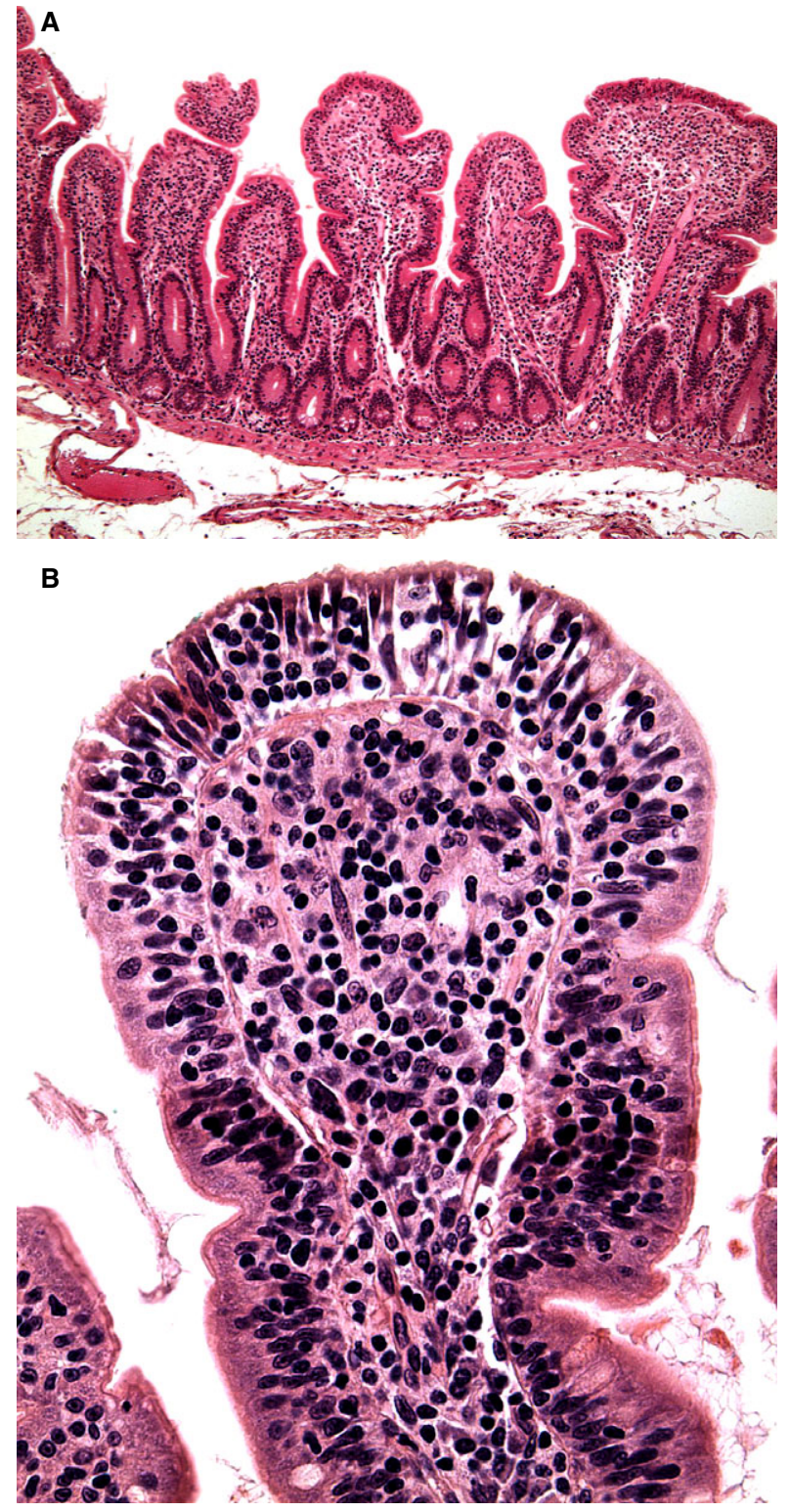

Figure 1. Tropical sprue. A, Low-power view of jejunum showing mild villous blunting with club-shaped villi. B, High-power view showing large numbers of intraepithelial lymphocytes.

$\mathrm{B}_{12}$ and folate deficiencies. It is very uncommon to find $\mathrm{B}_{12}$ deficiencies in coeliac disease patients. When comparing duodenal biopsies with terminal ileum biopsies in the same TS patients, Brown et al. noted more inflammation and damage in the terminal ileum. $^{2}$ This same study also found increased numbers of eosinophils and intraepithelial lymphocytes in colon biopsies in a subset of TS patients. ${ }^{2}$ Other studies have found that the earliest changes in TS are increased numbers of lamina propria mononuclear cells and intraepithelial lymphocytes, and that these 
changes first occur in the jejunum and then subsequently involve the ileum. ${ }^{4,14}$ It may take up to 4 months for villous blunting to develop. ${ }^{4}$ When $\mathrm{B}_{12}$ deficiencies are present, one may observe megaloblastic changes in the enterocyte nuclei analogous to the changes seen in the bone marrow of such patients (enlarged nuclei with decreased mitoses).

For most surgical pathologists, TS is a diagnosis arrived at after the initial diagnosis of probable coeliac disease has been proven wrong by negative serology findings and/or no response to a gluten-free diet. After all, in a day and age when receiving any clinical history with a GI biopsy is cause for celebration, obtaining a relevant travel history is exceedingly rare.

\section{Bacterial overgrowth (stasis/blind loop syndrome)}

As our understanding of the microbiome has expanded, so too has our understanding of how important this normal flora is to the overall health and function of the GI tract. Normally, the proximal small bowel has very few bacteria, owing to the low $\mathrm{pH}$ of the gastric juice that continuously assaults this region. In the jejunum, the motility of the luminal contents keeps the numbers of bacteria down, such that up to one-third of normal people have negative jejunal cultures. ${ }^{15,16}$ The bacteria that are present in the proximal small bowel mirror those of the oropharynx, and include largely aerobes, with some facultative anaerobes. ${ }^{15}$ The colon, on the other hand, has large numbers of bacteria, which are mostly anaerobes. The terminal ileum has much higher numbers of bacteria than the jejunum, and the type of bacteria is a mixture of those found in the colon and those found in the proximal small bowel. ${ }^{15}$

Small intestinal bacterial overgrowth (SIBO) has been defined as an increase in the number and/or a change in the type of bacteria in the upper gut. ${ }^{16}$ The gold standard for diagnosing this is to find $\geq 10^{5}$ colony-forming units per millilitre of proximal jejunal aspiration fluid. ${ }^{16}$ Others will consider a diagnosis of SIBO if there are $\geq 10^{3}$ colony-forming units of a bacterium that typically inhabits the colon. ${ }^{16}$ The easiest and least invasive way to test for SIBO is with a hydrogen breath test. ${ }^{15}$

Conditions that predispose to SIBO are largely those that decrease or interfere with small bowel motility (Table 1). Previous surgery, Crohn's disease, systemic sclerosis, neuromuscular disorders,
Table 1. Conditions associated with bacterial overgrowth (stasis syndrome)

Motor disturbances

Systemic sclerosis

Familial visceral myopathies and neuropathies

Diabetes mellitus/autonomic neuropathy

Parkinson's disease

Amyloidosis

Hypothyroidism

Structural abnormalities

Diverticula of small intestine

\begin{tabular}{l} 
Strictures and narrowings \\
Crohn's disease \\
\hline Tuberculosis \\
\hline
\end{tabular}

Adhesions

Surgically isolated segments

Pouches

Afferent limb in gastrojejunostomy

Enteroenterostomy

Miscellaneous

Coeliac disease

Chronic liver disease/cirrhosis

Chronic renal failure

Chronic pancreatitis

Immunodeficiencies

HIV

Common variable immunodeficiency

Advanced age

adhesions, diabetes mellitus and small bowel diverticula are some of the more common causes. ${ }^{15,16}$ Some have postulated that increased gastric $\mathrm{pH}$ resulting from proton pump inhibitors could also increase the risk of SIBO, but that this does not seem to be a major cause. ${ }^{16,17}$ Other risk factors include chronic pancreatitis, chronic liver or kidney disease, AIDS, coeliac disease, and advanced age. ${ }^{15,16,18}$ There is also a risk of developing bacterial overgrowth in ileal pouches. 
The abnormal bacteria lead to both malabsorption and maldigestion. Injury to the brush border can lead to decreased disaccharidase activity which, in turn, can lead to accumulation of increased amounts of complex sugars for the bacteria to metabolize. This metabolism leads to increased hydrogen production, which can be detected in breath testing. The bacteria can also compete for protein and vitamin $\mathrm{B}_{12}$, leading to deficiencies in these nutrients. ${ }^{16}$ In addition, the bacteria deconjugate bile acids, leading to fat and vitamin malabsorption. This combination typically leads to chronic diarrhoea and weight loss.

The mucosal histology is quite variable, such that it is very difficult, if not impossible, to diagnose SIBO conclusively in endoscopic biopsy material. A histological review by Lappinga et al. ${ }^{19}$ found that over half of their patients with culture-proven SIBO had normal biopsies. When abnormalities are present, there is often a modest degree of villous blunting, which may be accompanied by an increase in the number of lamina propria chronic inflammatory cells (Figure 2A). ${ }^{19,20}$ Intraepithelial neutrophils and/or lymphocytes may also be present/increased in number (Figure 2B). ${ }^{19}$ These findings are most often patchy and milder than the changes seen in fully developed coeliac disease; however, they are certainly in the differential diagnosis of a Marsh 1 lesion. When reviewing biopsies from cases of SIBO, one may initially have a feeling that the gestalt is not quite right, without being able to identify what exactly is wrong. Appropriate clinical history goes a long way in helping the pathologist to suggest the possibility of bacterial overgrowth. In resection specimens, one may find the root cause of the motility problem that leads to the SIBO, such as systemic sclerosis (Figure 2C), small bowel diverticular disease, or familial visceral myopathy.

Antibiotic therapy is the key to eradicating the abnormal bacteria and restoring order to the microbiome. The exact type and duration of antimicrobial therapy depend, to some degree, on the underlying condition. Patients with longstanding motility disorders may require multiple periodic or long-term courses of antibiotics.

\section{Autoimmune enteropathy}

Autoimmune enteropathy (AE) is a family of rare diseases that share a number of common themes. ${ }^{21-23}$ Although AE was initially described in children with intractable diarrhoea that developed in the first few weeks to months of life, there are well-established
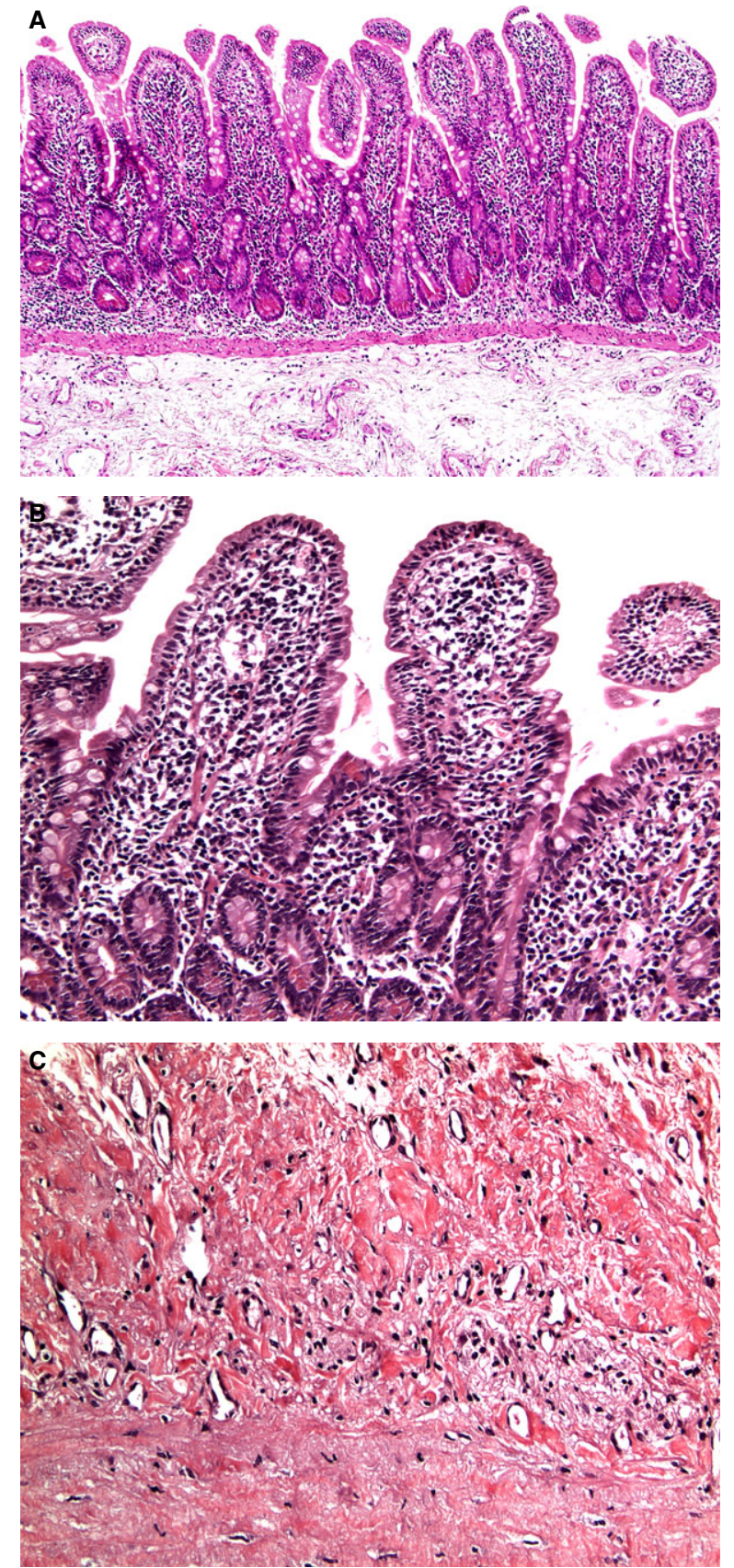

Figure 2. Bacterial overgrowth in progressive systemic sclerosis (scleroderma). A, Low-power view of jejunum showing moderate villous blunting with a somewhat hypercellular lamina propria. B, Higher-power view showing a mild increase in the number of intraepithelial lymphocytes. C, High-power view of muscularis propria showing dense collagen with an absence of smooth muscle fibres, a manifestation of the underlying collagen vascular disease and the cause of the bacterial overgrowth.

adult-onset cases as well. ${ }^{22-24}$ These diseases share the presence of anti-enterocyte antibodies (for the most part), and in many, if not most, cases are 
accompanied by some form of underlying immunodeficiency syndrome. ${ }^{22,23}$ Five diagnostic criteria have been proposed: (i) diarrhoea with a duration of $>6$ weeks; (ii) malabsorption; (iii) small bowel biopsy showing some degree of villous blunting with deep crypt lymphocytosis and apoptosis with minimal surface lymphocytosis; (iv) exclusion of other causes of villous atrophy, such as coeliac disease; and (v) antienterocyte or anti-goblet cell antibodies. ${ }^{25}$ Although one might think that anti-enterocyte antibodies would be the one steadfast requirement for the diagnosis of AE, several studies have found that 13-15\% of patients with $\mathrm{AE}$ have negative antibody findings. ${ }^{23,26}$ In addition, it has been shown that these autoantibodies are not specific for $\mathrm{AE}$, as patients with HIV, inflammatory bowel disease and even coeliac disease may have them. ${ }^{22}$ The antibodies will decrease or disappear with successful treatment of $\mathrm{AE}^{22} \mathrm{AE}$ patients may have other autoantibodies, such as anti-parietal cell antibodies, anti-islet cell antibodies, and antinuclear antibodies. ${ }^{22}$

Several phenotype-genotype relationships have emerged. Perhaps the most well-defined of these is the immune dysregulation, polyendocrinopathy and X-linkage (IPEX) syndrome. Young male patients with IPEX have been shown to have germline mutations in the FOXP3 gene on the X chromosome. ${ }^{27-29}$ The FOXP3 gene product is expressed in regulatory $\mathrm{T}$ cells, which play a critical role in immune function. ${ }^{23}$ Patients with IPEX syndrome may develop cytopenias, haemolytic anaemia, type 1 diabetes, atopic dermatitis, thyroiditis, thymic involution, arthritis, nephritis, and hepatitis. ${ }^{2,23}$ Given all of these afflictions, it is not surprising that IPEX patients have a poor prognosis.

Another inherited form of $\mathrm{AE}$ is autoimmune polyendocrinopathy, mucocutaneous candidiasis and ectodermal dystrophy (APECED) syndrome, which is an autosomal recessive condition. ${ }^{22,23}$ Patients typically present with Candida infections, and then progress to develop hypoparathyroidism or Addison's disease, and possibly autoimmune gastritis, autoimmune hepatitis, type 1 diabetes, thyroid disease, gonadal dysfunction, and hair and nail loss. ${ }^{22,23}$ The genetic defect is in the AIRE gene, which encodes a transcription factor affecting T-lymphocyte function. ${ }^{21,22}$

Other immunodeficiency states have been reported in patients with $\mathrm{AE}$, including common variable immunodeficiency and IgA deficiency. ${ }^{30}$ Mutations in the ITCH and MLL2 genes have also been reported in children with $\mathrm{AE}$ and other autoimmune disorders. ${ }^{21}$

Rare cases of adult-onset AE have been reported. ${ }^{21-23,31-33}$ These patients typically have
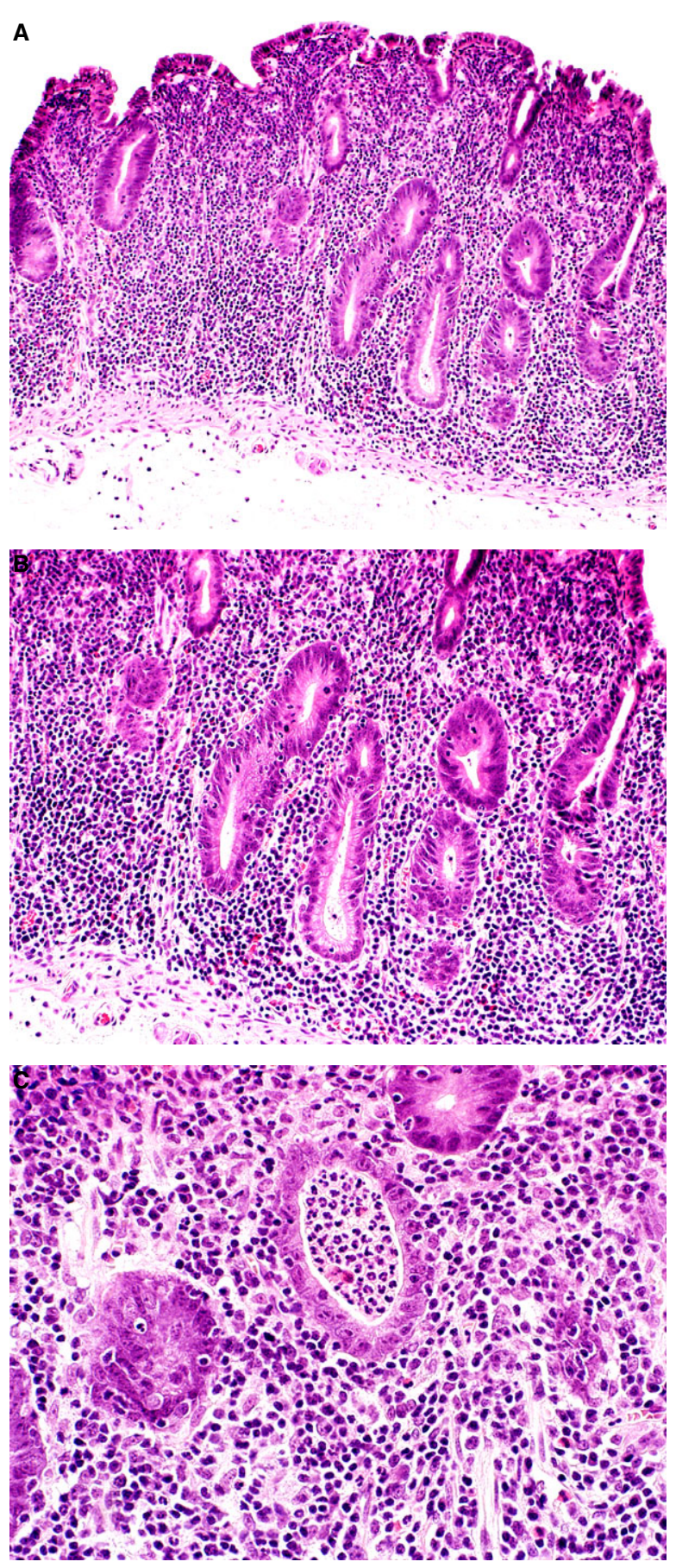

Figure 3. Autoimmune enteropathy. A, Low-power view of duodenum with complete villous flattening and intense chronic inflammation of the lamina propria. The surface epithelium is largely intact without many intraepithelial lymphocytes. Note the absence of goblet cells, Paneth cells, and endocrine cells (this patient had anti-goblet cell antibodies). B, Higher-power view of crypt bases showing intraepithelial lymphocytes and apoptotic cells. C, Highpower view of a crypt abscess and dense plasmacytosis of the deep lamina propria. Adjacent crypts contain apoptotic bodies and infiltrating lymphocytes. 
severe weight loss and malabsorption, and are initially thought to have coeliac disease. ${ }^{31}$ A handful of cases of $\mathrm{AE}$ have been reported in patients with thymomas, in keeping with the role of the thymus in immune regulation. ${ }^{33,34}$ In my own experience, some adult patients with $\mathrm{AE}$ have been taking the drug olmesartan, calling into question the diagnosis of $\mathrm{AE}$, despite these patients having anti-enterocyte antibodies. Perhaps the drug acts as a trigger for initiating the autoimmune reaction in these patients.

Autoimmune enteropathy patients have intractable secretory diarrhoea that does not respond to a gluten-free diet or total parenteral nutrition. ${ }^{35}$ The mainstay of therapy is immunosuppression with agents such as steroids, azathioprine, methotrexate, mycophenolate, tacrolimus, and cyclosporine. ${ }^{22,25}$ Newer agents such as infliximab, rituximab and abatacept have also been used with success. ${ }^{22,25}$

The histological features of AE have some overlap with coeliac disease, as both conditions will have villous blunting and crypt hyperplasia (Figure 3A). In $\mathrm{AE}$, however, there is not the intense surface intraepithelial lymphocytosis that one sees in coeliac disease. Instead, AE cases typically have apoptosis and lymphocyte infiltration at the base of the crypts (Figure 3B). Crypt abscesses and cryptitis are also

Table 2. Comparison of coeliac disease with non-coeliac enteropathies

\begin{tabular}{|c|c|c|c|c|c|}
\hline Diagnosis & Villus morphology & Lamina propria & Distribution & Other findings & $\begin{array}{l}\text { Laboratory } \\
\text { findings }\end{array}$ \\
\hline Coeliac disease & $\begin{array}{l}\text { Variable but often } \\
\text { flat. Always has } \\
\text { an increased } \\
\text { number of IELs }\end{array}$ & $\begin{array}{l}\text { Increased number } \\
\text { of plasma cells, } \\
\text { may have an } \\
\text { increased number } \\
\text { of eosinophils and } \\
\text { a few neutrophils }\end{array}$ & Duodenum > ileum & $\begin{array}{l}\text { May have } \\
\text { neutrophils in } \\
\text { epithelium in severe } \\
\text { cases. Associated } \\
\text { with lymphocytic } \\
\text { gastritis, } \\
\text { lymphocytic colitis, } \\
\text { and collagenous } \\
\text { colitis }\end{array}$ & $\begin{array}{l}\text { Anti-gliadin, } \\
\text { anti-reticulin and } \\
\text { anti-endomysial } \\
\text { antibodies as } \\
\text { well as anti-TTG } \\
\text { antibodies, HLA } \\
\text { DQ2-positive or } \\
\text { D8-positive }\end{array}$ \\
\hline Tropical sprue & $\begin{array}{l}\text { Mild to moderate } \\
\text { blunting with an } \\
\text { increased number } \\
\text { of IELs }\end{array}$ & $\begin{array}{l}\text { Increased } \\
\text { numbers of } \\
\text { plasma cells and } \\
\text { eosinophils }\end{array}$ & $\begin{array}{l}\text { lleum > duodenum. } \\
\text { May have colonic } \\
\text { involvement }\end{array}$ & $\begin{array}{l}\text { Atrophic glossitis, } \\
\text { megaloblastic } \\
\text { cytological changes }\end{array}$ & $\begin{array}{l}\mathrm{B}_{12} \text { and folate } \\
\text { deficiencies, } \\
\text { megaloblastic } \\
\text { anaemia }\end{array}$ \\
\hline $\begin{array}{l}\text { Bacterial } \\
\text { overgrowth }\end{array}$ & $\begin{array}{l}\text { Normal to } \\
\text { moderate } \\
\text { blunting. May } \\
\text { have an increased } \\
\text { number of IELs } \\
\text { and/or } \\
\text { neutrophils }\end{array}$ & $\begin{array}{l}\text { Normal to } \\
\text { increased number } \\
\text { of plasma cells }\end{array}$ & $\begin{array}{l}\text { Anywhere motility } \\
\text { is decreased }\end{array}$ & Table 1 & $\begin{array}{l}\text { Hydrogen } \\
\text { breath test }\end{array}$ \\
\hline $\begin{array}{l}\text { Autoimmune } \\
\text { enteropathy }\end{array}$ & $\begin{array}{l}\text { Usually flat. May } \\
\text { have a slightly } \\
\text { increased number } \\
\text { of IELs. Usually } \\
\text { has cryptitis } \\
\text { (neutrophils) }\end{array}$ & $\begin{array}{l}\text { Increased } \\
\text { numbers of } \\
\text { plasma cells and } \\
\text { lymphocytes }\end{array}$ & $\begin{array}{l}\text { Entire GI tract can } \\
\text { be involved }\end{array}$ & $\begin{array}{l}\text { GVHD-like } \\
\text { apoptosis with } \\
\text { lymphocytes } \\
\text { infiltrating crypt } \\
\text { bases. Lack of } \\
\text { goblet cells, } \\
\text { endocrine cells and } \\
\text { Paneth cells if } \\
\text { anti-goblet cell } \\
\text { antibodies present. } \\
\text { Associated with } \\
\text { immunodeficiency } \\
\text { states and } \\
\text { thymomas }\end{array}$ & $\begin{array}{l}\text { Anti-enterocyte } \\
\text { antibodies in } \\
75 \%, \\
\text { anti-goblet cell } \\
\text { antibodies in a } \\
\text { smaller subset. } \\
\text { Some patients } \\
\text { have } \\
\text { anti-parietal cell } \\
\text { antibodies }\end{array}$ \\
\hline
\end{tabular}

IEL, Intraepithelial lymphocyte; TTG, tissue transglutaminase. 
seen, and there is often an increase in the number of lamina propria mononuclear cells (Figure 3C). ${ }^{22,26}$ Patients with anti-goblet cell antibodies can have a lack of goblet cells, enteroendocrine cells and Paneth cells on biopsy (Figure $3 \mathrm{~A}-\mathrm{C}$ ). ${ }^{26,36}$ Many patients will have involvement of the entire gastrointestinal tract, and in some instances collagenous enteritis and/or collagenous colitis may be seen. ${ }^{22,26}$

Autoimmune enteropathy remains a rare and challenging diagnosis for both pathologists and clinicians. On encountering a diffusely inflamed and flattened small bowel biopsy with cryptitis and/or crypt abscesses, consideration should be given to the diagnosis of AE. The presence of apoptosis and/or lymphocytic infiltration at the crypt bases should further increase the level of suspicion.

\section{Conclusions}

In summary, this review of non-coeliac enteropathy has focused on TS, bacterial overgrowth, and AE. All three of these entities require clinicopathological correlation in order to differentiate them from coeliac disease and arrive at the correct diagnosis (Table 2).

\section{Conflict of interests}

The author has nothing to declare.

\section{References}

1. Baker SJ, Mathan VI. Syndrome of tropical sprue in India. Am. J. Clin. Nutr. 1968; 21; 984-993.

2. Brown IS, Bettington A, Bettington M, Rosty C. Tropical sprue: revisiting an underrecognized disease. Am. J. Surg. Pathol. 2014; 38; 666-672.

3. Ramakrishna BS. Tropical sprue: a riddle wrapped in a mystery inside an enigma. Indian J. Med. Res. 2013; 137; 12-14.

4. Haghighi P, Wolf PL. Tropical sprue and subclinical enteropathy: a vision for the nineties. Crit. Rev. Clin. Lab. Sci. 1997; 34; 313-341.

5. Batheja MJ, Leighton J, Azueta A, Heigh R. The face of tropical sprue in 2010. Case Rep. Gastroenterol. 2010; 4; 168-172.

6. Walker MM. What is tropical sprue? J. Gastroenterol. Hepatol. 2003; 18; 887-890.

7. Ghoshal UC, Ghoshal U, Ayyagari A et al. Tropical sprue is associated with contamination of small bowel with aerobic bacteria and reversible prolongation of orocecal transit time. J. Gastroenterol. Hepatol. 2003; 18; 540-547.

8. Mathan M, Mathan VI, Swaminathan SP, Yesudoss S. Pleomorphic virus-like particles in human faeces. Lancet 1975; 1; 1068-1069.

9. Cook GC. 'Tropical sprue': some early investigators favoured an infective cause, but was a coccidian protozoan involved? Gut 1996; 39; 428-429.
10. Menendez-Corrada R, Nettleship E, Santiago-Delpin EA. HLA and tropical sprue. Lancet 1986; 2; 1183-1185.

11. Schenk EA, Samloff IM, Klipstein FA. Morphologic characteristics of jejunal biopsy in celiac disease and tropical sprue. Am. J. Pathol. 1965; 47; 765-781.

12. Swanson VL, Thomassen RW. Pathology of the jejunal mucosa in tropical sprue. Am. J. Pathol. 1965; 46; 511-551.

13. Wheby MS, Swanson VL, Bayless TM. Comparison of ileal and jejunal biopsies in tropical sprue. Am. J. Clin. Nutr. 1971; 24; 117-123.

14. Tomkins A, Booth CC. In Booth CC, Neale G eds. Tropical Sprue. London: Blackwell Scientific Publications, 1985; 311332.

15. Quigley EM, Abu-Shanab A. Small intestinal bacterial overgrowth. Infect. Dis. Clin. North Am. 2010; 24; 943-959.

16. Bures J, Cyrany J, Kohoutova D et al. Small intestinal bacterial overgrowth syndrome. World J. Gastroenterol. 2010; 16; $2978-$ 2990.

17. Shmidt E, Smyrk TC, Boswell CL, Enders FT, Oxentenko AS. Increasing duodenal intraepithelial lymphocytosis found at upper endoscopy: time trends and associations. Gastrointest. Endosc. 2014; 80; 105-111.

18. Tursi A, Brandimarte G, Giorgetti G. High prevalence of small intestinal bacterial overgrowth in celiac patients with persistence of gastrointestinal symptoms after gluten withdrawal. Am. J. Gastroenterol. 2003; 98; 839-843.

19. Lappinga PJ, Abraham SC, Murray JA, Vetter EA, Patel R, Wu TT. Small intestinal bacterial overgrowth: histopathologic features and clinical correlates in an underrecognized entity. Arch. Pathol. Lab. Med. 2010; 134; 264-270.

20. Ament ME, Shimoda SS, Saunders DR, Rubin CE. Pathogenesis of steatorrhea in three cases of small intestinal stasis syndrome. Gastroenterology 1972; 63; 728-747.

21. Singhi AD, Goyal A, Davison JM, Regueiro MD, Roche RL, Ranganathan S. Pediatric autoimmune enteropathy: an entity frequently associated with immunodeficiency disorders. Mod. Pathol. 2014; 27; 543-553.

22. Gentile NM, Murray JA, Pardi DS. Autoimmune enteropathy: a review and update of clinical management. Curr. Gastroenterol. Rep. 2012; 14; 380-385.

23. Montalto M, D’Onofrio F, Santoro L, Gallo A, Gasbarrini A, Gasbarrini G. Autoimmune enteropathy in children and adults. Scand. J. Gastroenterol. 2009; 44; 1029-1036.

24. DeGaetani M, Tennyson CA, Lebwohl B et al. Villous atrophy and negative celiac serology: a diagnostic and therapeutic dilemma. Am. J. Gastroenterol. 2013; 108; 647-653.

25. Gupta NK, Yilmaz O, Fisher M, Yajnik V. Abatacept: a new treatment option for refractory adult autoimmune enteropathy. J. Clin. Gastroenterol. 2014; 48; 55-58.

26. Akram S, Murray JA, Pardi DS et al. Adult autoimmune enteropathy: Mayo Clinic Rochester experience. Clin. Gastroenterol. Hepatol. 2007; 5; 1282-1290.

27. Bacchetta R, Passerini L, Gambineri E et al. Defective regulatory and effector $\mathrm{T}$ cell functions in patients with FOXP3 mutations. J. Clin. Invest. 2006; 116; 1713-1722.

28. Le Bras S, Geha RS. IPEX and the role of Foxp3 in the development and function of human Tregs. J. Clin. Invest. 2006; 116; 1473-1475.

29. Ruemmele FM, Moes N, de Serre NP, Rieux-Laucat F, Goulet O. Clinical and molecular aspects of autoimmune enteropathy and immune dysregulation, polyendocrinopathy autoimmune enteropathy X-linked syndrome. Curr. Opin. Gastroenterol. 2008; 24; 742-748. 
30. Bishu S, Arsenescu V, Lee EY, Vargas HD, de Villiers WJ, Arsenescu R. Autoimmune enteropathy with a CD8+ CD7T-cell small bowel intraepithelial lymphocytosis: case report and literature review. BMC Gastroenterol. 2011; 11; 131-141.

31. Freeman HJ. Adult autoimmune enteropathy. World J. Gastroenterol. 2008; 14; 1156-1158.

32. Al Khalidi H, Kandel G, Streutker CJ. Enteropathy with loss of enteroendocrine and paneth cells in a patient with immune dysregulation: a case of adult autoimmune enteropathy. Hum. Pathol. 2006; 37; 373-376.
33. Elwing JE, Clouse RE. Adult-onset autoimmune enteropathy in the setting of thymoma successfully treated with infliximab. Dig. Dis. Sci. 2005; 50; 928-932.

34. Mais DD, Mulhall BP, Adolphson KR, Yamamoto K. Thymoma-associated autoimmune enteropathy. A report of two cases. Am. J. Clin. Pathol. 1999; 112; 810-815.

35. Russo PA, Brochu P, Seidman EG, Roy CC. Autoimmune enteropathy. Pediatr. Dev. Pathol. 1999; 2; 65-71.

36. Moore L, Xu X, Davidson G et al. Autoimmune enteropathy with anti-goblet cell antibodies. Hum. Pathol. 1995; 26; $1162-$ 1168. 